\title{
Ecology of the Caucasus populations and preimaginal stages of the crane-fly Tipula nigroantennata Sav. (Diptera: Tipulidae)
}

\author{
Экология кавказских попумящий и преимагинальные стадии \\ развития Tipula nigroantennata Sav. (Diptera: Tipulidae)
}

\section{V.I. Lantsov \\ В.И. Аанцов}

Laboratory of Invertebrate Diversity, Institute of Ecology of Mountain Territories of Kabardino-Balkarian Scientific Centre of Russian Academy of Science, Nalchik, 360051, Russia.

Лаборатория разнообразия беспозвоночных, Институт экологии горных территорий Кабардино-Балкарского научного центра РАН, Нальчик, 360051, Россия.

KEY WORDS: Crane-flies, Tipula nigroantennata, ecology, preimaginal stages, North Caucasus.

КЛЮЧЕВЫЕ СЛОВА: Комары-долгоножки, Tipula nigroantennata, экология, преимагинальные стадии развития, Северный Кавказ.

ABSTRACT. Data on geographical distribution, ecology and altitudinal occurrence of Tipula (Acutipula) nigroantennata Savchenko, 1961 in the North Caucasus are presented. Larvae of IV instar, male and female pupae are described.

РЕЗЮМЕ Приведены данные по географическому распространению, экологии и высотно-поясному распределению Tipula (Acutipula) nigroantennata Savchenko, 1961 на Северном Кавказе. Описаны личинка IV возраста, куколки самца и самки.

Tipula (Acutipula) nigroantennata Savchenko, 1961 was described from Teberda [Savchenko, 1961] as subspecies - Tipula (Acutipula) fulvipennis nigroantennata. Savchenko (1.c.) pointed it for the North Ossetia, Transcaucasia (Georgia, Abkhazia) and the Crimea. Later this species was noted for Armenia and Azerbaijan [Oosterbroek, Theowald, 1992], and for the North-East of Iran and Turkey [Koc, Oosterbroek, 2001; Oosterbroek, 2009, 2012]. Consequently the area of the species can be named as Crimean - Caucasian Southwestern Asian.

Brief data on ecology of the species were already presented [Savchenko, 1964; Lantsov, 2002a, b, 2005, 2007, 2011], but up to date the preimaginal stages of the species were unknown.

MATERIALS EXAMINED. All material presented was collected by the author. Specimens were preserved in $70^{\circ}$ alcohol, except some dry pinned specimens, which are noted separately.

Karachaevo-Cherkesia, Teberda, Teberda River valley (left side), spurs of Malay Hatipara mountain range: $2 \sigma^{7} \sigma^{7}$ (one specimen dry), two exuvium of pupae male, $1420 \mathrm{~m}$ a.s.l., larvae collected in litter in the stream near bank, 5.V.1999, pupation 1819.V.1999, emergence 30-31.V.1999; two larvae IV stage, same

Dedicated to Prof. Bella R. Striganova on the occasion of her 80th anniversary. place, weight 190 and $358 \mathrm{mg} ; 1$ pupae female,same place, larvae collected 5.V.1999, pupation 25-27.V.1999; 1 , exuvium of pupae female, mixed forest at the upper limit of forest zone, SE slope, $2150 \mathrm{~m}$ a.s.1., larvae $(379 \mathrm{mg}$ ) in the stream near spring (territory of cordon 3A) among litter collected, 5.V.1999, pupation 11-12.05., emergence 18-19.V.1999; 1 \%, exuvium of pupae female, $1700 \mathrm{~m}$ a.s.l., stream in mixed forest (a plot of fir forest), larvae collected in wet litter, 5.V.1999, pupation 16-17.V.1999, emergence 1920.V.1999; $1 \mathrm{O}^{\mathrm{T}}$ (dry pinned specimen), exuvium of pupae male, ibid., larvae 5.V.1999, pupation 11-12.V.1999, emergence 1819.V.1999; 1 q (dry specimen), exuvium pupae female, ibid., larvae 5.V.1999, pupation 11-12.V.1999, emergence 18-19.V.1999; 1 specimen larvae IV stage, ibid.; 1 specimen pupae male (damaged), $1300 \mathrm{~m}$ a.s.l., stream in beech forest, larvae in wet litter, 6.V.1999, pupation 17.V.1999.

Teberda, Ullu-Murudju river valley, right bank, $1 \mathrm{O}^{\top}$ (dry specimen), patch of pine forest on rocks among subalpine meadows, 2090 m a.s.l., 5 VIII 1998.

Kabardino-Balkaria, Severnoe Prielbrusje (North Elbrus region): $1 O^{\text {T }}$ (dry specimen), Baksan River basin, meadow communities on slopes, $2050 \mathrm{~m}$ a.s.1., 12.VI.1997; $2 \mathrm{O}^{7} \mathrm{O}^{7}$ (dry specimens), Chegem River basin, Bashil River valley, left bank, swamped meadow with small lake near the path to Abaji-Su fall, $2020 \mathrm{~m}$

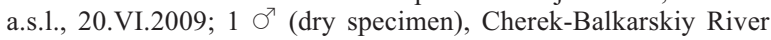
valley, a plot of the broad-lived forest very close to swamped slope, $1420 \mathrm{~m}$ a.s.1., 28.VI.2006.

METHODS. Larvae and pupae were selected in situ from wet plant debris by hand or using wet sieving. Imago hatching was done in histological glasses (9.5$10 \mathrm{~cm}$ in height, $3-3.5 \mathrm{~cm}$ in diameter) with cotton stoppers. Larval material was briefly put into boiling water and preserved in $70 \%$ alcohol. Larvae were weighed alive using torsion balance. The standard practice of preparing the samples was used in the process of imaginal material definition.

In colour rendering in the preimaginal stage the colour scale according to Bondartsev [1954] was used. In the description of larvae and pupae the terminology of Theowald [1967] in Savchenko's interpretation [1983] was used. The typology of variants of the Caucasus vertical zonation is given according to Sokolov and Tembotov [1989]. 
ECOLOGY. Within the Greater Caucasus the species is found on both macroslopes. According to data available [Savchenko, 1964] the species is registered in Colchian (Upper Svanetia), Adzharian (Adzhar-Imereti Range) and also in Trialeti (Borjomi) and AlazanAgrichai (Lagodekhi) variants of vertical zonation. Unfortunately, in Savchenko's publication (1.c.) there is no exact data on habitats for each point of sampling. However it is noted that the species is found "... along the stream verges and mountain streamlets at altitudes of about 1000 and more metres above sea level. It is more common in the subalpine zone". This, also concerns the material collected in the North Caucasus (Teberda, North Ossetia).

According to Savchenko (1.c.) and our data in the North Caucasus the area of the species embraces Terskiy (North Ossetia, Vartseiskiy Gorge, in the vicinity of Zaremag Village), Elbrus (river basins of Baksan, Chegem, Cherek-Balkarskiy) and Kuban (Teberda) variants of vertical zonation. In all variants of vertical zonation the species occupies intrazonal and azonal biotopes, the only difference is that, for example, in an Elbrus variant of vertical zonation, which is characterised by the absence of the pronounced belt of broadleaved forests, Tipula nigroantennata habitat preference is intrazonal communities with hyper-humidification - to hygrophyte and marshy meadows on slopes with constant humidification or to similar marshy meadows in valley floors with spring feed. In Terek and Kuban variants of vertical zonation of the species is found in a broad-leaved forests belt, and also in communities of mixed forests (within the belt of dark coniferous forests) where it is confined to intrazonal biotopes and is found on stream verges and rivulet banks.

We believe that the species can be identified only for convenience to the group of high-altitude species [Lantsov, 2007] and is more likely mid-high-altitude as the range of its altitude-zone distribution is much wider - from 1000 to $2150 \mathrm{~m}$ a.s.l.

The collected larvae are found in litter and plant residues in water within a litoral zone and in boggy areas of stream verges and rivulet banks [Lantsov, 1.c.]. Larvae are hydrophilous helobionts [Lantsov, 2011]. Larvae of III-IV stage are likely saprophagous (detritus and plant residues are found in an intestine) but possibly also predators. The density of larvae was registered only once and amounted 10 specimens $/ \mathrm{m}^{2}$ (Teberda, $1420 \mathrm{~m}$ a.s.1. - see above the list of the examined material) [Lantsov, 2005]. Female fecundity was 236-318 eggs (two females examined). The duration of pupae development at room temperature - 813 days. The species is common, but does not reach high density. Flight occurs from May to August.

OVAE AND FOURTH INSTAR LARVAE. Ovae are of elliptical shape, dark-brown, horion without visible structure. Ovae of the subgenus Acutipula usually have a filament — as e.g. Tipula (Acutipula) luna Westhoff, 1879 [Savchenko, 1983]. The specimens of females investigated were fixed in $75^{\circ}$ alcohol and this could be the reason that the tissues of ovary were very tough, and the cap (twisted and compressed filament) could not be found on ovae. The question on the presence of filament on ovae of T. nigroantennata is still open - it is necessary to inspect ovae just hatched by female. The length of an egg is $1.07 \pm 0.01 \mathrm{~mm}$, width $0.45 \pm 0.01 \mathrm{~mm}$.

Coloration of the alcohol preserved larva is from beige to dark-smoky (a living larva has a darker coloration) due to microtrichia covering the body. Pleurites and sternites of abdominal segments has a lighter coloration. On tergitae of thoracic and abdominal segments microtrichia form either gyrose catenae, or rather uniform integument. Mandiblae are massive with obtuse apex. A suboral sclerite (hypostome) has 7 teeth (Fig. 1).

Microtrichia on a prothoracic segment are very small and can be seen only at the large magnification (8 õ 4), they cover a tergite surface of a prothoratic segment more or less evenly. On tergite of meso- and metathorax, microtrichia are better visible and can be seen at lesser magnification (8 õ 1, 8 õ 2). Especially well microtrichia can be seen on VI-VIII segments that gives their coloration a dirty-yellow-grey tinge - on tergites V-VIII abdominal segments they set off setiferous pores and macrotrichia. On terga of II, III thoracic segments large microtrichia are concentrated in close proximity to setiferous pores and microtrichia, forming six, clumps, on each segment, standing out against the general background.

On tergite of I-III abdominal segments the density and length of microtrichia is approximately identical and they are arranged more or less evenly. On tergitae of VI (partially), VII-VIII abdomen segments microtrichia actually look like very thin miniature hairs. On tergite of V-VIII segments they do not form a continuous integument but form a peculiar net with free «semimembranous areas» (according to Savchenko, 1983: 110-111) (setiferous pores) which for the most part are deprived of microtrichia, so the surface of tergite looks spotted (to examine at magnification 80̃2). This net is noticeable both on the main (basal), and on topmost (apical) segment rings.

The spiracle area of anal segment (Fig. 2) is edged by a fringe of short setae. Separate large distal setae are arranged on an outer and inner margin side of the spiracle area lobes. Spiracles are spaced $0.75 \mathrm{~mm}$ apart, rounded, from 0.45 to $0.5 \mathrm{~mm}$ in diameter, a surface between them with a small excavation. A spiracle area is weakly sclerotized. Lightcoloured yellow-orange sclerites cover an internal surface of dorsal and lateral lobes. More intensively pigmented yellowish elongate sclerites are on the lower inner edge of lateral lobes. The only intensively sclerotized black sclerites are on abdominal lobes: one pair is at the base of the lobes, the second one - in their distal part (Fig. 3). The latter look like extended ovals and occupy from one third to half of abdominal lobes length. Apices of sclerites with clearly marked setiferous pore and large setula. Anus is 

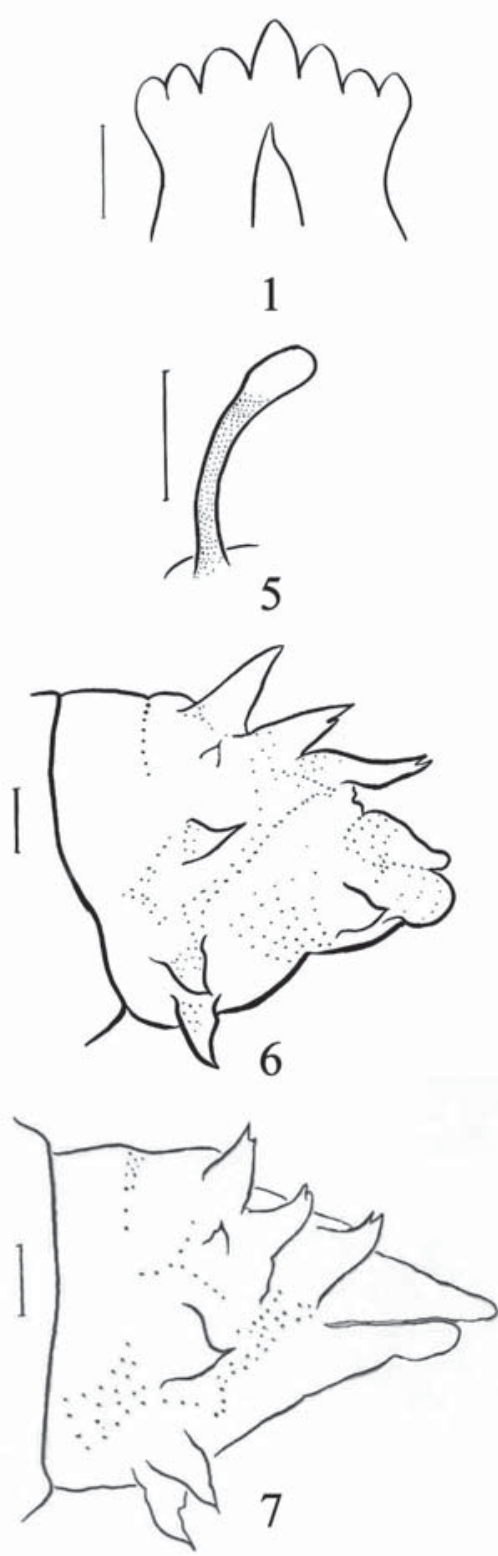
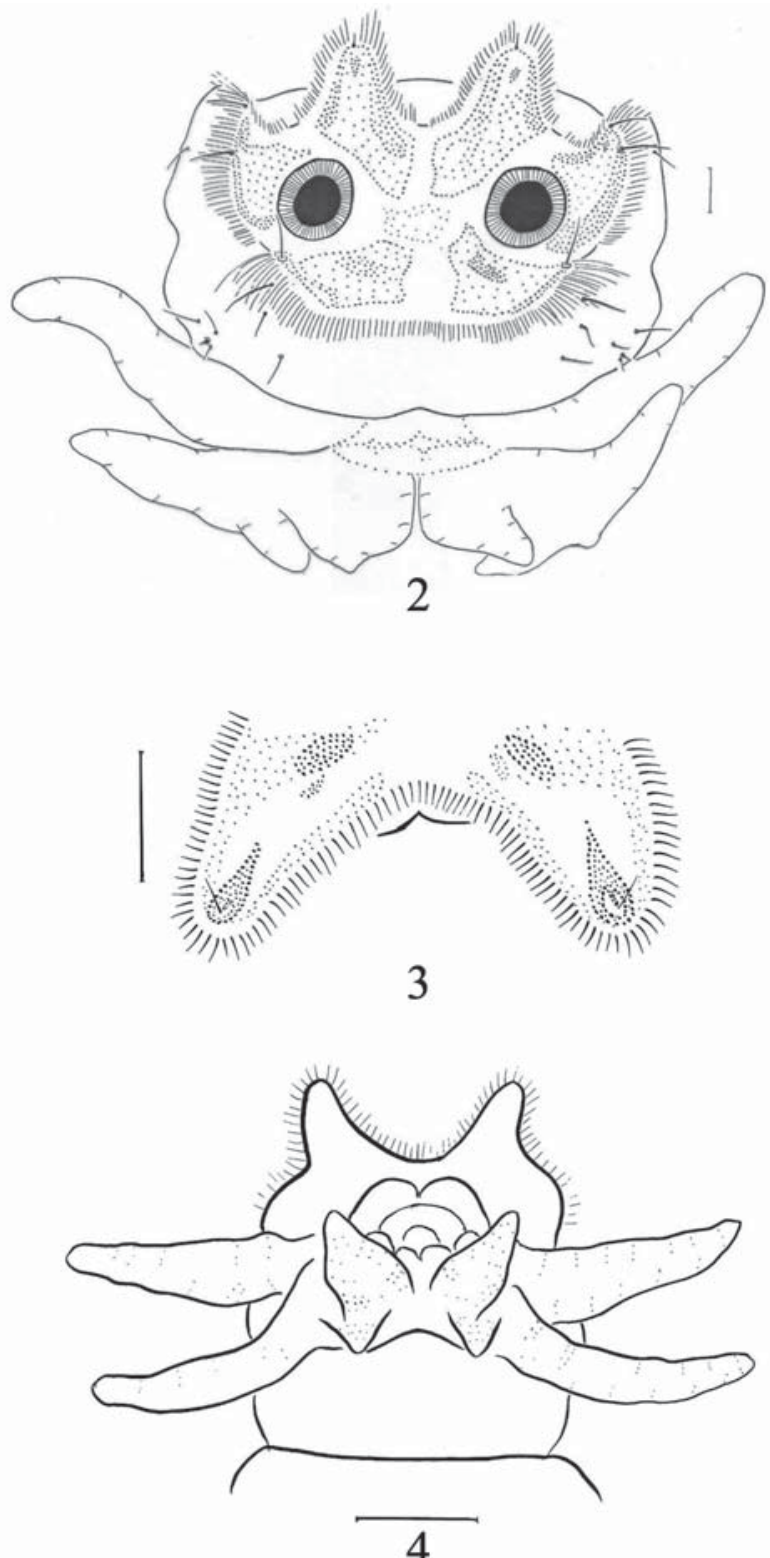

Figs 1-7. Morphology of forth instar larvae, pupae male and female of Tipula nigroantennata Sav. 1-4 - forth instar larvae: 1 suboral sclerite (hypostome) in ventral view; 2 - spiracle area in caudal view; 3 - ventral lobes of spiracle area in dorsal view; 4 tracheal gills in ventral view; 5-7 — pupae male and female: mesothoracic respiratory process of the male pupae in lateral view (5); VIII abdominal segment of male (6) and female (7) pupae in lateral view. Scale bars $=0.15 \mathrm{~mm}(1), 0.25 \mathrm{~mm}(2), 0.5 \mathrm{~mm}(3,6,7), 1 \mathrm{~mm}(4,5)$.

Рис. 1-7. Морфология личинки IV возраста, куколок самца и самки Tipula nigroantennata Sav. 1-4 - личинка IV возраста: 1 - подротовой склерит вентрально; 2 - стигмальное поле каудально; 3 - брюшные выросты стигмального поля дорсально; 4 - жаберные мешки вентрально; 5-7 - среднегрудная дыхательная трубочка куколки самца, латерально (5), VIII сегмент куколки самца (6) и самки (7), латерально. Масштаб 0,15 мм (1), 0,25 мм (2), 0,5 мм (3, 6, 7), 1 мм (4, 5).

transverse. Tracheal gills (anal papillae) (Fig. 4) are introduced by a pair of upper (distal) and a pair of lower (proximal) ones - their length is $1.75 \mathrm{~mm}$ that approximately is 3.5 times. as wide as the base. At the base of the lower pair of tracheal gills there are two pairs of large well-pronounced conoid papillae, one of which are consider sometimes as separate pare of tracheal gills.
The length of an adult IV instar larva preserved in alcohol is $26-31 \mathrm{~mm}$.

PUPAE MALE AND FEMALE. Male and female pupa - from dark to light brown, exuvium fixed in alcohol - light brown. The surface of mesonotum is crimped and slightly tuberous in places. Mesothoracic respiratory processes of the male and female pupa (Fig. 5) are well-pronounced - thin long, from 1.4 to $2 \mathrm{~mm}$ 
that approximately exceeds 9 times their width at the base. The peduncle of horns is crimped and has a flattened weakly-marked clava the surface of which looks smooth exteriorly. Sheaths of middle and hind legs of the male pupa exuvium cover $2 / 3$ of IV abdominal segment, in female - reach a back edge of the III abdominal segment. Wings sheaths do not reach a little the back edge of the II segment of an abdomen.

The number of spurs on tergites of VII, VI and V abdomenal segments of the male is rather variable 6-11, 7-12, 7-15 spurs accordingly. On sternites of VII, VI and V abdominal segments of the male pupa there are two sets of spurs - hind and anterior that is characteristic for the subgenus Acutipula [Savchenko, 1983], - in a hind set there are 5-10, 8-11 and 8-12 spurs accordingly (besides large spurs small ones were also considered), in an anterior set there are always two large spurs (both males and females).

The number of spurs (especially small) on tergites and sternites of abdominal segments of female pupas varies. The number of spurs on terga of VII, VI, V abdominal segments of the female pupa: $6-11,8-16(10$ large, 6 small) and 9-14 accordingly. The number of spurs on sternites of the same segments (in a hind set): 8-10, 9-12, 9-13 accordingly. At an anterior set on sternites of these segments there are always two spurs.

Tergite VIII of abdominal segment of male and female pupa (Fig. 6) has six large spines -2 middledorsal spines, 2 lateral-dorsal spines and 2 posteriodorsal spines (according to Savchenko, 1983), the latter are larger and more massive. Besides, male and female pupae have one little spur at the bottom of each lateral dorsal spine on its outer side. The sternite of VIII segment in both females and males has 4 well-marked spurs.

Posterio-dorsal spines on the VIII female pupa segment (Fig. 7) are biapicate, lateral-dorsal spines with a small preapical projection on the back side. Valves sheaths do not reach the apex of cerci sheaths a little.

The length of straightened and preserved in alcohol exuvia of the male and female pupa is $24-26 \mathrm{~mm}$.

COMPARISON. The fourth instar larva T. nigroantennata according to the constitution of an anal segment (concerning to pigmentation of a spiracle area and the form of tracheal gills) is similar to larvae of allied species of the subgenus Acutipula - Tipula (Acutipula) fulvipennis De Geer, 1776, Tipula (Acutipula) bosnica Riedel, 1913 and Tipula (Acutipula) maxima Poda, 1761, but differs from them in number, size and form of dark-pigmented sclerites on an inside of abdominal lobes of a spiracle area, and also by relatively larger pairs of well-pronounced conoid processes (papillae) at the base of the lower pair of tracheal gills.

The arrangement and form of spines on the VIII segment of male and female pupae $T$. nigroantennata is similar to that of pupae Tipula (Acutipula) luna Westhoff, 1879, T. maxima and Tipula (Acutipula) vittata Meigen, 1804 [Theowald, 1967]. The difference is in the presence of two marginal complementary small spurs at the base of lateral dorsal spines on their outer side in pupae species under examination.

\section{References}

Bondartsev A.S. 1954. [Colour scale. (Guade for biologist in science and scientific-applied researches)]. Moskva, Leningrad: AN SSSR Publ. 27 p. [in Russian].

Koc H., Oosterbroek P. 2001. Checklist of Turkish Tipulidae (Diptera), with new records // Studia Dipterologica. Vol.8. P.463-468.

Lantsov V.I. 2002a. [Larvae of crane-flies (Diptera, Tipulidae) in soils of the Central and North-Western Caucasus] // Biogeografiya pochv. Mezhdunarodnaya konferentsiya. Konferentsiya posvyashchena 90 letiyu so dnya rozhdeniya akad M.S. Gilyarova. Syktyvkar, Respublika Komi, Rossiya, Sentyabr, 16-20, 2002. Tezisy dokladov. P.77-78 [in Russian], 201 [in English].

Lantsov V.I. 2002b. [Fauna structure and horology of crane-flies (Diptera, Tipulidae) of Teberdinskiy state biosfere preserve] // Biologicheskoe raznoobrasie Kavkasa. Trudy II regionalnoy konferentsii. Sukhum, 18-23 sentyabrya 2001 g. P.108-121 [in Russian]

Lantsov V.I. 2005. [Research of tipuloid dipterans (Diptera, Tipuloidea) of mountain territories of Palaearctic, their diversity and cenotic role in arctic and mountain communities] // Gornye ekosistemy i ikh komponenty. Trudy mezhdunarodnoy konferentsii. 4-9 sentyabrya 2005, Nalchik. Vol.1. P.192-199 [in Russian].

Lantsov V.I. 2007. [Crane-flies (Diptera, Tipulidae) of high altitude landscapes of the Caucasus] // Gornye ekosistemy i ikh komponenty. Trudy mezhdunarodnoy konferentsii. 13-18 avgusta 2007, Nalchik. Moscow: Tovarishestvo nauchnykh izdaniy KMK. Chast 2. P.94-99 [in Russian].

Lantsov V.I. 2011. [Ecological groups of tipuloidaea larvae (Diptera, Tipuloidea) of the Caucasus] // Problemy pochvennoy zoologii. Materialy XVI vserossiyskogo soveschaniya po pochvennoy zoologii. 4-7 oktyabrya 2011, Rostov-na-Donu. Moskva - Rostov-na-Donu. P.69-71 [in Russian].

Oosterbroek P. 2009. New distributional records for Palaearctic Limoniidae and Tipulidae(Diptera: Craneflies), mainly from the collection of the Zoological Museum, Amsterdam // Lantsov V. (ed.). Crane flies. History, taxonomy and ecology (Diptera: Tipulidae, Limoniidae, Pediciidae, Trichoceridae, Ptychopteridae, Tanyderidae). Memorial volume dedicated to Dr. Charles Paul Alexander (1889-1981), Dr. Bernhard Mannheims (1909-1971) and Dr. Evgeniy Nikolaevich Savchenko (1909-1994). Zoosymposia. Vol.3. P.179-197.

Oosterbroek P. 2012. Catalogue of the Craneflies of the World (CCW) // http://ip30.eti.uva.nl/ccw/index.php (latest update: 10 March 2012).

Oosterbroek P., Theowald B. 1992 Tipulidae // Catalogue of Palaearctic Diptera. Vol.1. Trichoceridae - Nymphomyiidae. Budapest: Hungarian Natural History Museum. P.183-369.

Savchenko E.N. 1961. [Crane-flies (Fam. Tipulidae), Subfam. Tipulinae, Genus Tipula L., (part 1)] // Fauna SSSR. Novaya seriya No.79. Nasekomye dvukrylye [Diptera]. Vol.2. No.3. Moskva - Leningrad: Nauka Publ. 487 p. [in Russian].

Savchenko E.N. 1964. [Crane-flies (Diptera, Tipulidae) in the high mountains fauna of the Great Caucasus in Georgia] // Fauna vysokogoriya Bolshogo Kavkaza v predelakh Gruzii. Tbilisi: AN Gryzinskoy SSR. P.87-90 [in Russian].

Savchenko E.N. 1983. [Crane-flies (Fam. Tipulidae), Introduction, and beginning of systematic part. Subfam. Dolichopezinae, subfam. Tipulinae (start)] // Fauna SSSR. Novaya seriya. No.127. Nasekomye dvukrylye [Diptera]. Vol.2. No.1-2. Leningrad: Nauka Publ., Leningradskoe otdelenie.585 p. [in Russian].

Sokolov V.E., Tembotov A.K. 1989. [Mammals of the Caucasus: Insectivorous]. Moscow: Nauka Publ. 548 p. [in Russian].

Theowald B. 1967. Familie Tipulidae (Diptera, Nematocera). Larven and Puppen // Bestimmungsbücher zur Bodenfauna Europas. Berlin: Akademie-Verlag. Lfg.7. S.1-10. 